\title{
Endophytic bacteria associated with halophyte Seidlitzia rosmarinus Ehrenb. ex Boiss. from saline soil of Uzbekistan and their plant beneficial traits
}

\author{
Vyacheslav SHURIGIN ${ }^{1 *}$, Dilfuza EGAMBERDIEVA ${ }^{2,3}, \mathrm{LI} \mathrm{Li}^{2}, \mathrm{Kakhramon}$ DAVRANOV ${ }^{4}$, \\ Hovik PANOSYAN ${ }^{5}$, Nils-Kåre BIRKELAND ${ }^{6}$, Stephan WIRTH ${ }^{3}$, \\ Sonoko D BELLINGRATH-KIMURA ${ }^{3,7}$ \\ ${ }^{1}$ Faculty of Biology, National University of Uzbekistan, Tashkent 100174, Uzbekistan; \\ ${ }^{2}$ Key Laboratory of Biogeography and Bioresource in Arid Land, Xinjiang Institute of Ecology and Geography, Chinese \\ Academy of Sciences, Urumqi 830011, China; \\ ${ }^{3}$ Leibniz Centre for Agricultural Landscape Research (ZALF), Müncheberg 15374, Germany; \\ ${ }^{4}$ Institute of Microbiology of the Academy of Sciences of the Republic of Uzbekistan, Tashkent 100128, Uzbekistan; \\ ${ }^{5}$ Department of Biochemistry, Microbiology and Biotechnology, Yerevan State University, Yerevan 0025, Armenia; \\ ${ }^{6}$ Department of Biological Sciences, University of Bergen, NO-5020 Bergen 7803, Norway; \\ ${ }^{7}$ Faculty of Life Science, Humboldt University of Berlin, Berlin 14195, Germany
}

\begin{abstract}
Endophytic bacteria of halophytic plants play essential roles in salt stress tolerance. Therefore, an understanding of the true nature of plant-microbe interactions under extreme conditions is essential. The current study aimed to identify cultivable endophytic bacteria associated with the roots and shoots of Seidlitzia rosmarinus Ehrenb. ex Boiss. grown in the salt-affected soil in Uzbekistan and to evaluate their plant beneficial traits related to plant growth stimulation and stress tolerance. Bacteria were isolated from the roots and the shoots of S. rosmarinus using culture-dependent techniques and identified by the 16S rRNA gene. RFLP (Restriction Fragment Length Polymorphism) analysis was conducted to eliminate similar isolates. Results showed that the isolates from the roots of $S$. rosmarinus belonged to the genera Rotbia, Kocuria, Pseudomonas, Staphylococcus, Paenibacillus and Brevibacterium. The bacterial isolates from the shoots of S. rosmarinus belonged to the genera Staphylococcus, Rothia, Stenotrophomonas, Brevibacterium, Halomonas, Planococcus, Planomicrobium and Pseudomonas, which differed from those of the roots. Notably, Staphylococcus, Rotbia and Brevibacterium were detected in both roots and shoots, indicating possible migration of some species from roots to shoots. The root-associated bacteria showed higher levels of IAA (indole-3-acetic acid) synthesis compared with those isolated from the shoots, as well as the higher production of ACC (1-aminocyclopropane-1-carboxylate) deaminase. Our findings suggest that halophytic plants are valuable sources for the selection of microbes with a potential to improve plant fitness under saline soils.
\end{abstract}

Keywords: endophytic bacteria; phylogenetic analysis; halophyte; auxin; plant beneficial traits

Citation: Vyacheslav SHURIGIN, Dilfuza EGAMBERDIEVA, LI Li, Kakhramon DAVRANOV, Hovik PANOSYAN, Nils-Kåre BIRKELAND, Stephan WIRTH, Sonoko D BELLINGRATH-KIMURA. 2020. Endophytic bacteria associated with halophyte Seidlitzia rosmarinus Ehrenb. ex Boiss. from saline soil of Uzbekistan and their plant beneficial traits. Journal of Arid Land, 12(5): 730-740. https://doi.org/10.1007/s40333-020-0019-4

\section{Introduction}

Salinity is considered to be a major threat to the environment and for food security, as it can affect biodiversity and reduce agricultural production and yield (Announ et al., 2004; Egamberdieva et al.,

\footnotetext{
*Corresponding author: Vyacheslav SHURIGIN (E-mail: slaventus87@inbox.ru)

Received 2020-02-26; revised 2020-06-04; accepted 2020-06-19

(C) Xinjiang Institute of Ecology and Geography, Chinese Academy of Sciences, Science Press and Springer-Verlag GmbH Germany, part of Springer Nature 2020
} 
$2017 \mathrm{a}, \mathrm{b})$. Under saline conditions, only a few highly tolerant plants, i.e., halophytes withstand high salinity levels. Thus, revegetation of saline soils with halophytes is considered as a potential phytoremediation approach (El Shaer, 2010; Egamberdieva et al., 2015; Mishra and Tanna, 2017). Moreover, the introduction of perennial and annual halophytes in salt-affected soils helps to improve soil structure and to increase soil organic biomass, soil biodiversity and activity, as well as crop productivity (Toderich et al., 2008; Hasanuzzaman et al., 2014; Flowers and Colmer, 2015). Halophytes have developed different morphological and physiological strategies to thrive under salinity stress, including the regulation of stress-responsive genes (Grigore et al., 2014; Muchate et al., 2016), the generation of reactive oxygen species and active osmoregulation (Hashem et al., 2016). There is also evidence that salt stress tolerance of halophytes is modulated by endophytic bacteria that colonize internal tissues (Etesami and Beattie, 2017).

The roles of endophytes in plant stress tolerance and growth stimulation under abiotic stress conditions have been reported in several studies (Ludwig-Mueller, 2015; Hashem et al., 2016; Egamberdieva et al., 2017; Etesami and Beattie, 2018). There is now clear evidence for the mechanisms used by endophytic bacteria to induce stress tolerance and to stimulate plant growth, such as the synthesis of plant growth hormones, the modulation of plant metabolites and the inhibition of ethylene synthesis in roots through 1-aminocyclopropane-1-carboxylate (ACC) deaminase (Kaplan et al., 2013; Cho et al., 2015; Egamberdieva et al., 2017; Etesami and Beattie, 2018). Mora-Ruiz et al. (2016) found a clear difference in the diversity of endophytes in the aerial and below-ground parts of Arthrocnemum macrostachyum, a flowering plant in the Amaranthaceae family. The colonization of plant tissue by endophytes originated in the rhizosphere, and followed by migration to the aerial parts of the plant.

Halophytic plants harbor diverse endophytic bacteria, e.g., Chromohalobacter canadensis, Rudaea cellulosilytica, Psychrobacter sp., Bradyrhizobium sp. and Halomonas sp. were found in A. macrostachyum (Mora-Ruiz et al., 2016). Bacillus sp., Serratia sp., Rhodococcus sp., Thalassospira sp., Rhizobium sp., Salinicola sp., Hafnia sp., Streptomyces sp., Microbacterium sp. were isolated from the halophyte Salicornia europaea L. (Szymańska et al., 2016), belonging to the family Chenopodiaceae. Zhao et al. (2016) isolated the endophytes Bacillus endophyticus, B. tequilensis, Planococcus rifietoensis, Variovorax paradoxus and Arthrobacter agilis from tissues of S. europaea. The endophytic isolates associated with Salicornia brachiate L. were identified as Brachybacterium saurashtrense sp. nov., Zhihengliuella sp., Brevibacterium casei, Haererehalobacter sp., Halomonas sp., Vibrio sp., Cronobacter sakazakii, Pseudomonas sp., Rhizobium radiobacter and Mesorhizobium sp. (Jha et al., 2012).

To date, there have been no reports of endophytes associated with halophytes from salt-affected arid lands of Central Asia. Thus, here, we report on the endophytic bacteria associated with Seidlitzia rosmarinus Ehrenb. ex Boiss., a perennial woody shrub belonging to the Amaranthaceae family found in deserts and the arid and salt-affected regions in Jordan, Iraq, Iran, Saudi Arabia, and Central Asia. The plant is highly salt-tolerant and can grow on substrates up to $500 \mathrm{mM} \mathrm{NaCl}$ and is extremely well adapted even to hypersaline conditions (Kurkova et al., 2002). The shrub is used as a fodder crop for camels and is also considered for phytoremediation of salt-affected soils (Hadi, 2009), thus providing commercial value and ecological importance. To improve plant fitness to abiotic and biotic stresses, an enhanced understanding of plant and microbial interactions under extreme conditions is essential. The aims of our study were: (1) to isolate and identify cultivable endophytic bacteria associated with the roots and shoots of $S$. rosmarinus grown in salt-affected soil by using 16S rRNA gene analysis; and (2) to evaluate plant beneficial traits of endophytic bacteria related to plant growth stimulation and stress tolerance.

\section{Materials and methods}

\subsection{Plant sample collection}

Seidlitzia rosmarinus Ehrenb. ex Boiss was collected from the foothills of a mountain not far from Tuzkon salt cave in the Surkhandarya Province, Uzbekistan in August 2017. The soil has an EC (electrical conductivity) value of $6.5 \mathrm{mS} / \mathrm{cm}$. Three individual plants over a distance of $10-12 \mathrm{~m}$ 
were collected as a whole, stored in zip-lock plastic bags using sterile gloves and transported to the laboratory. The roots were separated from the stems with a sterile scalpel and were rinsed in water to remove the soil attached to the roots. Approximately $10 \mathrm{~g}$ of the plant roots and shoots were prepared for the isolation of endophytic bacteria.

\subsection{Isolation of endophytic bacteria}

The roots and shoots (stems with leaves together) were separated with a sterile scalpel, sterilized with $99.9 \%$ ethanol for $2 \mathrm{~min}$ and subsequently with $10 \% \mathrm{NaClO}$ and were rinsed five times in sterile distilled water. The sterile shoots and roots (10 g fresh weight) were cut into $3-4 \mathrm{~cm}$ pieces and macerated using a sterile mortar and pestle (Mora-Ruiz et al., 2015). The macerated tissue ( $1 \mathrm{~g}$ ) was transferred into plastic tubes with $9 \mathrm{~mL}$ of sterile phosphate-buffered saline (PBS) (20 mM sodium phosphate, $150 \mathrm{mM} \mathrm{NaCl}, \mathrm{pH}$ 7.4) and shaken for 1 min using a Biosan B-1 Vortex (Microspin FV-2400; BIOSAN, Riga, Latvia). About $100 \mu \mathrm{L}$ aliquot from dilutions $\left(10^{1}-10^{5}\right)$ was spread on 30\% Tryptic Soy Agar plates (TSA) (BD, Difco Laboratories, Detroit, USA) supplemented with nystatin $50 \mu \mathrm{g} / \mathrm{mL}$, and the plates were incubated for $4 \mathrm{~d}$ at $28^{\circ} \mathrm{C}$. The content of $30 \% \mathrm{TSA}$ (tryptone soya agar) was as follows: $4.5 \mathrm{~g} / \mathrm{L}$ pancreatic digest of casein, $1.5 \mathrm{~g} / \mathrm{L}$ enzymatic digest of soya bean, $5.0 \mathrm{~g} / \mathrm{L} \mathrm{NaCl}$ and $15.0 \mathrm{~g} / \mathrm{L}$ agar. After $4 \mathrm{~d}$, colonies with different shape, color and density were picked and carefully transferred by streaking on nutrient agar plates, and incubated for the next $72 \mathrm{~h}$ to check the purity of the isolates. Visually homological colonies in sizes, shapes and colors were checked under a microscope for purity and used for DNA isolation. In order to test the sterility of the outer surfaces of the plant parts after sterilization with ethanol, we put two uncut pieces of roots and shoots onto TSA media, and the absence of any colonies after $72 \mathrm{~h}$ confirmed that sterilization was successful.

\subsection{DNA isolation}

For DNA extraction, the heat treatment method (Dashti et al., 2009) was used. The small parts of the colonies were transferred into 2-mL Eppendorf tubes with $1.5 \mathrm{~mL}$ of sterile MQ-water and were mixed with a Biosan B-1 Vortex for $10 \mathrm{~s}$. The tubes were incubated at $90^{\circ} \mathrm{C}$ for $20 \mathrm{~min}$ in a Dry Block Heater (IKA Works, Inc., Wilmington, USA) and centrifuged at 12,000 rpm for $5 \mathrm{~min}$. The DNA-containing supernatant was taken and stored at $-20^{\circ} \mathrm{C}$. The presence of DNA was checked by horizontal gel electrophoresis $\left(0.8 \%\right.$ agarose) and was quantified with a NanoDrop ${ }^{\text {TM }}$ One (Thermo Fisher Scientific Inc., Waltham, USA).

\subsection{Polymerase chain reaction (PCR)}

Extracted DNA was used as a template for 16S rRNA gene analysis. The 16S rRNA genes were amplified via PCR using the following primers: 27F (5'-GAGTTTGATCCTGGCTCAG-3') and 1492R (5'-GAAAGGAGGTGATCCAGCC-3') (Sigma-Aldrich, St. Louis, Missouri, USA) (Lane, 1991). Each $25 \mu \mathrm{L}$ of reaction mixture contained $1 \mu \mathrm{L}(15-40 \mathrm{ng})$ DNA, $5 \mu \mathrm{L} 5 \times$ OneTaq standard reaction buffer (BioLabs, New England), $0.5 \mu \mathrm{L} 10 \mathrm{mM}$ dNTP mix (Thermo Scientific), $0.5 \mu \mathrm{L} 10$ $\mathrm{mM}$ primer 16SF (Merck), $0.5 \mu \mathrm{L} 10 \mathrm{mM}$ primer 16SR (Merck) $(25 \mu \mathrm{mol} / \mathrm{mL}), 1 \mu \mathrm{L} 0.1 \%$ bovine serum albumin (TaKaRa Bio Inc., USA), $0.125 \mu \mathrm{L}$ One Taq polymerase (BioLabs, New England), and $16.375 \mu \mathrm{L}$ Milli Q water. The PCR was performed using a PTC-200 thermocycler (Bio-Rad Laboratories, USA). The PCR program was as follows: a primary heating step for $30 \mathrm{~s}$ at $94^{\circ} \mathrm{C}$, followed by 30 cycles of denaturation for $15 \mathrm{~s}$ at $94^{\circ} \mathrm{C}$, annealing for $30 \mathrm{~s}$ at $55^{\circ} \mathrm{C}$ and extension for $1.5 \mathrm{~min}$ at $68^{\circ} \mathrm{C}$, followed by the final step for $20 \mathrm{~min}$ at $68^{\circ} \mathrm{C}$. The PCR-amplified products were examined by electrophoresis in a $0.8 \%$ agarose gel containing GelRed.

\subsection{Restriction fragment length polymorphism (RFLP) analysis}

To determine the difference of the isolates similar in their color, shape and size, we conducted RFLP analysis of PCR amplicons of 16S rRNA gene as described by Jinneman et al. (1996). The fragments of digested PCR amplicons were checked via gel electrophoresis (1\% agarose gel). After the electrophoresis, the gel was visualized using a digital gel imaging system (Gel-Doc XR TM+, 
Bio-Rad Laboratories, USA) to identify identical isolates and reduce the number of strains to be sequenced.

\subsection{Sequencing and phylogenetic analysis}

Before being sequenced, we purified the PCR products with the USB ${ }^{\circledR}$ ExoSAP-IT ${ }^{\circ}$ PCR Product Cleanup Kit (Affymetrix, USB ${ }^{\circledR}$ Products, USA) according to the manufacturer's protocol. Sequencing was performed using an ABI PRISM BigDye 3.1 Terminator Cycle Sequencing Ready Reaction Kit (Applied Biosystems, USA) by the manufacturer's protocol. Received data were analyzed and corrected using Chromas software v2.6.5. Corrected sequences were manually merged using EMBOSS Explorer (http://emboss.bioinformatics.nl/). The sequences were compared with those registered in GenBank from the National Center for Biotechnology Information (NCBI) (http://www.ncbi.nlm.nih.gov/) using basic local alignment search tool (BLAST).

All sequences were multiply aligned using ClustalX software v2.1, and a FASTA format file was used to construct the phylogenetic tree. The evolutionary history was inferred using the Neighbor-Joining method (Saitou and Nei, 1987). The optimal tree with the sum of branch length of 0.96928586 is shown. The percentage of replicate trees in which the associated taxa clustered together in the bootstrap test (500 replicates) is shown next to the branches (Felsenstein, 1985). The tree is drawn to scale, with branch lengths in the same units as those of the evolutionary distances used to infer the phylogenetic tree. The evolutionary distances were computed using the Maximum Composite Likelihood method (Tamura et al., 2004) and were in the units of the number of base substitutions per site. The analysis involved 35 nucleotide sequences. All positions containing gaps and missing data were eliminated. There were a total of 1278 positions in the final dataset. Evolutionary analyses were conducted in Molecular Evolutionary Genetics Analysis v6.0 (Tamura et al., 2013).

\subsection{Accession numbers}

The 16S rRNA gene sequences of the endophytic bacteria of S. rosmarinus were deposited into GenBank under the accession numbers: MH311985-MH311991 for root endophytes and MH311992-MH312003 for shoot endophytes.

\subsection{Plant beneficial traits}

IAA (indole-3-acetic acid) production was studied following the description of Bano and Musarrat (2003). The calibration curve of pure IAA was used as a standard to calculate IAA concentrations in culture supernatants. The utilization of ACC deaminase by endophytic bacteria as the sole $\mathrm{N}$ source was also determined. The bacterial isolates were grown in basal medium supplemented with $3.0 \mathrm{mM}$ of ACC (Sigma Chemical Co., St. Louis, Missouri, USA) to test ACC utilization, or of $\left(\mathrm{NH}_{4}\right)_{2} \mathrm{SO}_{4}$ (positive control) as the sole $\mathrm{N}$ source or without added $\mathrm{N}$ source (negative control) (Egamberdieva et al., 2011).

\subsection{Plant growth stimulation assay}

Analysis of the plant growth stimulation capacity of endophytic bacteria was performed by using cress-lettuce (Lepidium sativum L.) seedlings. The bacterial isolates were grown for $3 \mathrm{~d}$ in nutrient broth at $28^{\circ} \mathrm{C}$. Seeds of cress-lettuce were sterilized with $1 \%$ sodium hypochlorite solution followed by $95 \%$ ethanol for $3 \mathrm{~min}$ and were rinsed five times with sterile distilled water. The sterilized seeds were soaked for $10 \mathrm{~min}$ in bacterial suspension at a cell density of $1 \times 10^{7}$ cells $/ \mathrm{mL}$ and were germinated on $1 / 2$ agar plate supplemented with $100 \mathrm{mM} \mathrm{NaCl}$. The untreated seeds were soaked with corresponding medium only. Each plate received 15 seeds and was kept in a plant growth chamber for $5 \mathrm{~d}$. The germination rate, lengths of the roots and stems of seedlings were measured. All experiments were conducted in three replications.

\subsection{Statistical analysis}

Data were tested for statistical significance using the analysis of variance package included in Microsoft Excel 2010. Comparisons were performed using Student's $t$-test. Mean comparisons were conducted using the least significant difference (LSD) test $(P=0.05)$. 


\section{Results}

\subsection{Isolation and identification of cultivable endophytic bacteria}

A total of 45 bacterial isolates were isolated from root and shoot tissues of the halophytic plant $S$. rosmarinus (Fig. 1).

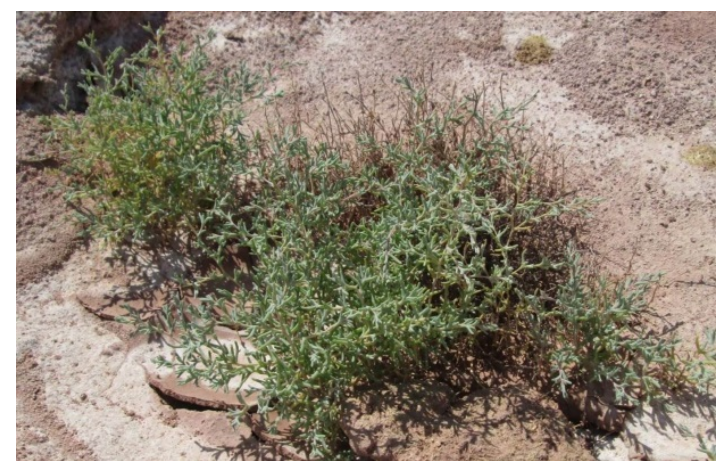

Fig. 1 Seidlitzia rosmarinus growing on saline soil in the Surkhandarya Province, Uzbekistan

Only 19 isolates were obtained after RFLP analysis, in which 7 isolates were obtained from the roots (Table 1) and 12 from the shoots (Table 2). The 16S rRNA gene sequence similarities of endophytic bacteria isolated from the roots of $S$. rosmarinus with sequences from GenBank are shown in Table 1.

Table 1 Sequence similarities of endophytic bacteria isolated from the roots of Seidlitzia rosmarinus with sequences registered in GenBank

\begin{tabular}{|c|c|c|c|c|c|}
\hline \multicolumn{3}{|c|}{ Isolated strain sequence } & \multicolumn{3}{|c|}{ Closest match among bacteria (16S rRNA gene) } \\
\hline Strain & $\begin{array}{l}\text { Length } \\
\text { (bp) }\end{array}$ & $\begin{array}{c}\text { Accession } \\
\text { number }\end{array}$ & Species & Accession number & Identity (\%) \\
\hline JRT1 & 1452 & MH311985 & Rothia terrae & NR_043968 & 99.1 \\
\hline JRT2 & 1450 & МH311986 & Kocuria palustris & NR_026451 & 98.9 \\
\hline JRT3 & 1452 & MH311987 & Pseudomonas baetica & NR_116899 & 98.9 \\
\hline JRT4 & 1450 & MH311988 & Staphylococcus warneri & NR_025922 & 99.1 \\
\hline JRT5 & 1471 & MH311989 & Staphylococcus epidermidis & NR_113957 & 99.1 \\
\hline JRT6 & 1460 & MH311990 & Paenibacillus amylolyticus & NR_025882 & 98.7 \\
\hline JRT7 & 1466 & МH311991 & Brevibacterium frigoritolerans & NR_115064 & 99.6 \\
\hline
\end{tabular}

All strains provided $98.4 \%-99.6 \%$ identities to those registered in GenBank. Isolated strains belonged to three phyla: Actinobacteria (JRT1, JRT2), Proteobacteria (JRT3) and Firmicutes (JRT4, JRT5, JRT6 and JRT7). The isolates were identified as Rothia terrae JRT1, Kocuria palustris JRT2, Pseudomonas baetica JRT3, Staphylococcus warneri JRT4, Staphylococcus epidermidis JRT5, Paenibacillus amylolyticus JRT6 and Brevibacterium frigoritolerans JRT7 (Table 1; Fig. 2). The diversity of isolates from the shoots of $S$. rosmarinus is shown in Table 2.

In total, 12 different isolates from the shoots of S. rosmarinus were selected after RFLP analysis. Isolated strains belonged to three phyla: Actinobacteria (JST2), Proteobacteria (JST3, JST7 and JST12) and Firmicutes (JST1, JST4, JST5, JST6, JST8, JST9, JST10 and JST11). The isolates JRT1, JRT2 and JST2 represent the same family Micrococcaceae, and it should be noted that the strains representing $R$. terrae inhabit both the roots and the shoots of $S$. rosmarinus. The same applies to $S$. warneri, S. epidermidis and B. frigoritolerans.

All isolated strains of the phylum Proteobacteria were predominantly related to the class Gammaproteobacteria, but from different orders, i.e., Pseudomonadales (JRT3 and JST12), Xanthomonadales (JST3) and Oceanospirillales (JST7). Representatives of the phylum Firmicutes were related to the order Bacillales and four families: Bacillaceae (JRT7 and JST5), Paenibacillaceae 


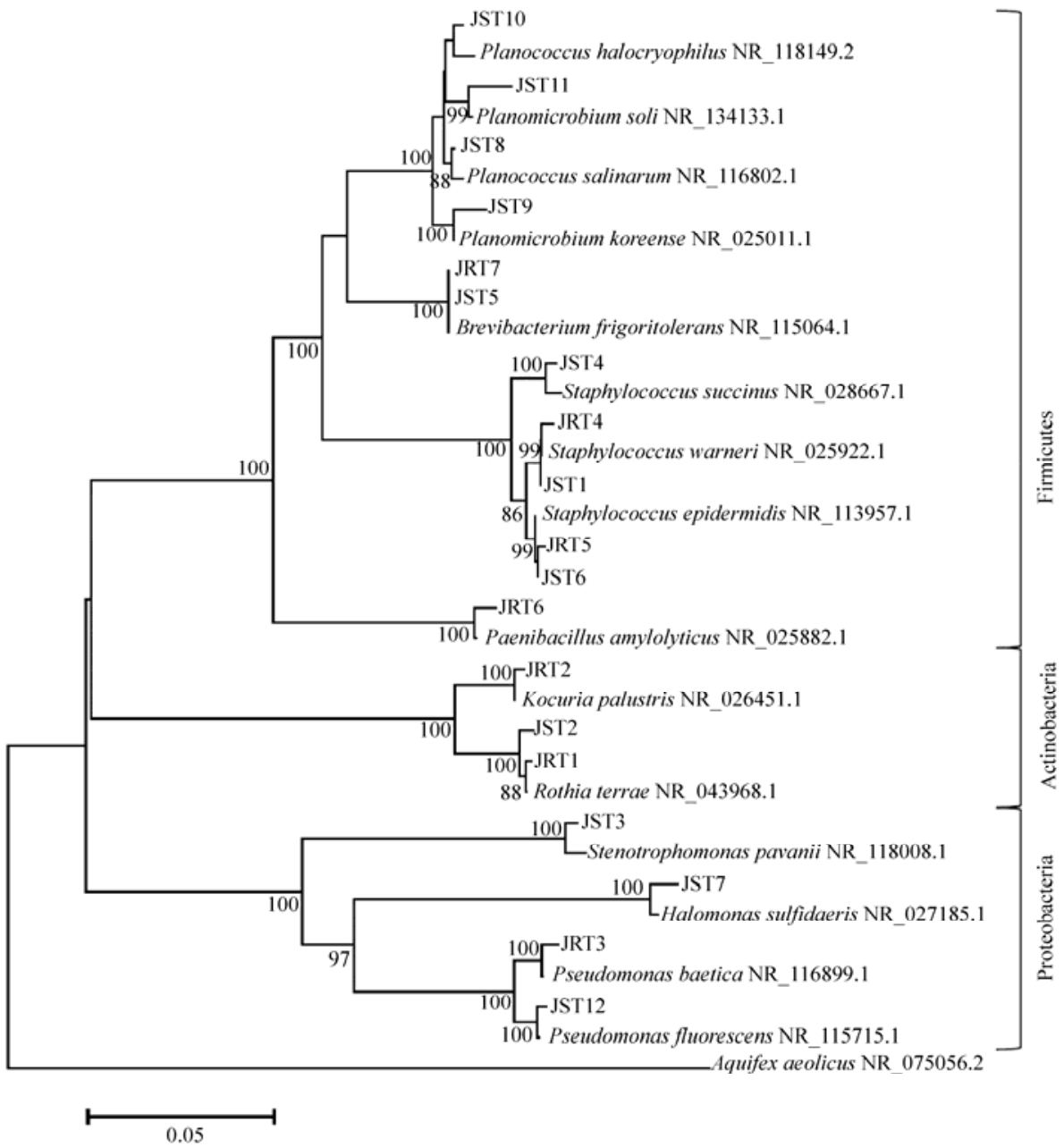

Fig. 2 Neighbor-joining phylogenetic tree based on 16S rRNA gene sequences isolated from endophytic bacteria of Seidlitzia rosmarinus, showing the relationship of isolated strains to their closest relatives in GenBank. All presented strains were divided into three groups: Firmicutes, Actinobacteria and Proteobacteria.

Table 2 Sequence similarities of endophytic bacteria isolated from the shoots of Seidlitzia rosmarinus with sequences registered in GenBank

\begin{tabular}{|c|c|c|c|c|c|}
\hline \multicolumn{3}{|c|}{ Isolated strain sequence } & \multicolumn{3}{|c|}{ Closest match among bacteria (16S rRNA gene) } \\
\hline Strain & $\begin{array}{l}\text { Length } \\
\text { (bp) }\end{array}$ & $\begin{array}{c}\text { Accession } \\
\text { number }\end{array}$ & Species & Accession number & Identity $(\%)$ \\
\hline JST1 & 1474 & MH311992 & Staphylococcus warneri & NR_025922 & 99.6 \\
\hline JST2 & 1445 & MH311993 & Rothia terrae & NR_043968 & 98.7 \\
\hline JST3 & 1467 & MH311994 & Stenotrophomonas pavanii & NR_118008 & 98.4 \\
\hline JST4 & 1474 & MH311995 & Staphylococcus succinus & NR_028667 & 98.6 \\
\hline JST5 & 1471 & MH311996 & Brevibacterium frigoritolerans & NR_115064 & 99.4 \\
\hline JST6 & 1458 & MH311997 & Staphylococcus epidermidis & NR_113957 & 99.4 \\
\hline JST7 & 1442 & MH311998 & Halomonas sulfidaeris & NR_027185 & 98.8 \\
\hline JST8 & 1478 & MH311999 & Planococcus salinarum & NR_116802 & 98.7 \\
\hline JST9 & 1471 & MH312000 & Planomicrobium koreense & NR_025011 & 98.5 \\
\hline JST10 & 1476 & MH312001 & Planococcus halocryophilus & NR_118149 & 98.9 \\
\hline JST11 & 1454 & MH312002 & Planomicrobium soli & NR_134133 & 98.5 \\
\hline JST12 & 1464 & MH312003 & Pseudomonas fluorescens & NR_115715 & 98.6 \\
\hline
\end{tabular}


(JRT6), Planococcaceae (JST8, JST9, JST10 and JST11) and Staphylococcaceae (JRT4, JRT5, JST1, JST4 and JST6).

According to species diversity, the representatives of Firmicutes phyla (12 species) were more numerous as compared with Actinomycetes ( 3 isolates) and Proteobacteria (4 isolates) in both the roots and shoots of $S$. rosmarinus. A phylogenetic tree constructed showed the closest relatives of the isolates to known species (Fig. 2).

\subsection{Plant beneficial traits}

We characterized several plant growth traits of endophytes isolated from $S$. rosmarinus. The results showed that 6 out of 7 root-associated bacteria produced IAA, whereas 7 out of 12 shoot-associated bacteria produced IAA (Table 3 ).

Among the studied isolates from the roots, the following isolates showed the IAA production potential: R. terrae JRT1, K. palustris JRT2, P. baetica JRT3, S. warneri JRT4, S. epidermidis JRT5, $P$. amylolyticus JRT6 and $B$. frigoritolerans JRT7. The highest IAA synthesis was observed in the root-associated bacteria P. baetica JRT3 $(14.9 \mu \mathrm{g} / \mathrm{mL})$ and P. amylolyticus JRT6 $(15.8 \mu \mathrm{g} / \mathrm{mL})$. The

Table 3 Production of IAA (indole-3-acetic acid) and ACC (1-aminocyclopropane-1-carboxylate) deaminase activities in endophytic isolates of Seidlitzia rosmarinus and plant growth promoting abilities

\begin{tabular}{|c|c|c|c|c|c|c|}
\hline \multirow{2}{*}{ Isolated strain } & \multicolumn{2}{|c|}{$\begin{array}{c}\text { IAA production } \\
(\mu \mathrm{g} / \mathrm{mL})\end{array}$} & \multirow{2}{*}{$\begin{array}{c}\text { ACC } \\
\text { deaminase }\end{array}$} & \multicolumn{2}{|c|}{ Plant growth stimulation $(\mathrm{cm})$} & \multirow{2}{*}{$\begin{array}{c}\text { Seed } \\
\text { germination } \\
\text { percentage } \\
(\%)\end{array}$} \\
\hline & Tr- & $\operatorname{Tr}+$ & & Roots & Shoots & \\
\hline R. terrae JRT1 & $8.4 \pm 0.7$ & $11.7 \pm 1.0$ & + & $5.2 \pm 0.5^{*}$ & $5.4 \pm 0.5$ & $89 \pm 4$ \\
\hline K. palustris JRT2 & $8.9 \pm 0.7$ & $12.5 \pm 0.8$ & + & $5.4 \pm 0.6^{*}$ & $5.5 \pm 0.6$ & $90 \pm 6$ \\
\hline P. baetica JRT3 & $10.1 \pm 0.8$ & $14.9 \pm 1.0$ & + & $5.5 \pm 0.5^{*}$ & $5.5 \pm 0.6$ & $92 \pm 5$ \\
\hline S. warneri JRT4 & $3.8 \pm 0.4$ & $4.0 \pm 0.4$ & - & $4.7 \pm 0.5$ & $4.8 \pm 0.5$ & $82 \pm 5$ \\
\hline S. epidermidis JRT5 & $4.8 \pm 0.5$ & $8.9 \pm 0.5$ & - & $4.9 \pm 0.5$ & $5.1 \pm 0.5$ & $85 \pm 5$ \\
\hline P. amylolyticus JRT6 & $11.4 \pm 0.9$ & $15.8 \pm 1.1$ & + & $5.4 \pm 0.6^{*}$ & $5.5 \pm 0.5$ & $91 \pm 6$ \\
\hline B. frigoritolerans JRT7 & 0.0 & 0.0 & + & $4.8 \pm 0.5$ & $5.1 \pm 0.5$ & $85 \pm 6$ \\
\hline S. warneri JST1 & 0.0 & $0.8 \pm 0.4$ & - & $4.6 \pm 0.4$ & $5.0 \pm 0.5$ & $85 \pm 5$ \\
\hline R. terrae JST2 & $8.4 \pm 0.7$ & $11.7 \pm 1.0$ & + & $5.2 \pm 0.5^{*}$ & $5.4 \pm 0.5$ & $89 \pm 5$ \\
\hline S. pavanii JST3 & $9.5 \pm 0.7$ & $20.5 \pm 0.9$ & + & $5.5 \pm 0.6^{*}$ & $5.6 \pm 0.6^{*}$ & $93 \pm 4$ \\
\hline S. succinus JST4 & $7.1 \pm 0.6$ & $10.9 \pm 0.9$ & - & $5.1 \pm 0.5$ & $5.3 \pm 0.5$ & $87 \pm 6$ \\
\hline B. frigoritolerans JST5 & 0.0 & 0.0 & + & $4.9 \pm 0.5$ & $5.2 \pm 0.4$ & $85 \pm 5$ \\
\hline S. epidermidis JST6 & $3.3 \pm 0.5$ & $6.5 \pm 0.5$ & - & $4.7 \pm 0.4$ & $5.1 \pm 0.5$ & $85 \pm 4$ \\
\hline H. sulfidaeris JST7 & 0.0 & $1.7 \pm 0.8$ & + & $4.9 \pm 0.5$ & $5.1 \pm 0.4$ & $85 \pm 4$ \\
\hline P. salinarum JST8 & 0.0 & 0.0 & - & $4.6 \pm 0.5$ & $4.9 \pm 0.4$ & $83 \pm 5$ \\
\hline P. koreense JST9 & $7.8 \pm 0.7$ & $9.9 \pm 0.9$ & + & $5.1 \pm 0.6$ & $5.3 \pm 0.6$ & $88 \pm 6$ \\
\hline P. halocryophilus JST10 & 0.0 & $1.0 \pm 0.4$ & - & $4.7 \pm 0.4$ & $5.0 \pm 0.5$ & $85 \pm 5$ \\
\hline P. soli JST11 & $9.3 \pm 0.7$ & $12.3 \pm 0.8$ & + & $5.4 \pm 0.5^{*}$ & $5.4 \pm 0.5$ & $90 \pm 6$ \\
\hline P. fluorescens JST12 & $7.2 \pm 1.3$ & $11.6 \pm 1.5$ & + & $5.6 \pm 0.6^{*}$ & $5.7 \pm 0.6^{*}$ & $94 \pm 4$ \\
\hline Control & & & & $4.8 \pm 0.5$ & $5.1 \pm 0.5$ & $85 \pm 5$ \\
\hline
\end{tabular}

Note: Tr-, without tryptophan; Tr+, with tryptophan; +, ACC deaminase production; -, non-ACC deaminase production. ${ }^{*}$ means significant difference between isolated strain and control at $P<0.05$ level. Mean \pm SE.

shoot-associated bacteria that produced IAA belonged to $R$. terrae JST2, $S$. pavanii JST3, S. succinus JST4, S. epidermidis JST6, P. koreense JST9, P. soli JST11 and P. fluorescens JST12. ACC deaminase production was observed in 5 out of 7 bacterial isolates from the root system and 7 out of 12 isolates from the shoots (Table 3).

Table 3 illustrates plant growth stimulation capabilities of endophytic isolates on lettuce. The results showed that $K$. palustris JRT2, $P$. baetica JRT3 and P. amylolyticus JRT6 isolated from roots, stimulated roots and shoots of lettuce seedlings by $12 \%, 15 \%$ and $13 \%$, respectively, as compared 
with the control seedlings. However, only S. warneri JRT4 reduced the growth of lettuce seedlings. Similarly, the isolates from the shoots also showed significant plant growth stimulatory capabilities, although four isolates, i.e., S. warneri JST1, S. epidermidis JST6, $P$. salinarum JST8 and $P$. halocryophilus JST10, showed inhibitory activity. The highest stimulatory percentage was obtained with P. fluorescens JST12 (17\%), followed by S. pavanii JST3 (14\%).

\section{Discussion}

To our knowledge, this is the first report in which endophytic bacteria associated with the halophyte $S$. rosmarinus growing on salt-affected soils were analyzed. In total, 19 isolates were selected, and we found that the majority of the isolates (i.e., 12 isolates) were from the Firmicutes phylum, divided into four clusters: Bacillaceae, Paenibacillaceae, Planococcaceae and Staphylococcaceae. The Actinobacteria phylum contained three isolates, belonging to Kocuria and Rothia genera. The Proteobacteria phylum contained four isolates, belonging to Pseudomonas, Stenotrophomonas and Halomonas genera. In our study, the endophytic bacteria $P$. halocryophilus and $P$. salinarum were associated with the roots of $S$. rosmarinus. Zhao et al. (2016) also identified P. rifietoensis associated with Salicornia europaea growing on a highly saline soil. P. rifietoensis was also found in permafrost soil from the Canadian Arctic region (Mykytczuk et al., 2012). Yoon et al. (2010) observed a strain of $P$. salinarum in a marine solar saltern in Korea. The strains $R$. terrae JRT1 and $R$. terrae JST2 were isolated from root and shoot tissues of $S$. rosmarinus in the present study. The occurrence of this bacterium was also observed in a soil from Taiwan, China (Chou et al., 2008). In our study, one of the shoot-associated bacterial species was identified as P. koreense. Yoon et al. (2001) observed a strain similar to P. koreense JST9 from fermented seafood in Korea. The species P. soli was first isolated from soil of Alxa National Geological Park in Inner Mongolia Autonomous Region, China (Luo et al., 2014). The identification of the isolate H. sulfidaeris in our study is the first report of the occurrence of halotolerant $H$. sulfidaeris in plant tissue. You et al. (2015) also observed several Halomonas species, including $H$. sulfidaeris from rhizosphere soils of coastal plants from the Dokdo Islands of South Korea. Previously, this species was found in Pacific hydrothermal vents, similar to many other halotolerant microorganisms (Kaye and Baross, 2000).

We have observed five isolates from the roots and the shoots of $S$. rosmarinus belonging to Staphylococcus species, such as S. warneri JRT4, S. epidermidis JRT5, S. warneri JST1, S. succinus JST4 and S. epidermidis JST6. The representatives of the genus Staphylococcus are commonly known as potential human or animal pathogens (Kloos and Schleifer, 1975; Nováková et al., 2006). For example, S. warneri causes bovine abortion (Barigye et al., 2007) or multifocal discitis (Announ et al., 2004). There are also several reports of the occurrence of salt-tolerant Staphylacoccus species in diverse environments, including saline soils (Roohi et al., 2012; Nanjani and Soni, 2014). For example, S. saprophyticus was isolated from the rhizosphere of wheat grown in saline soil (Egamberdieva et al., 2008), from carrot (Surette et al., 2003), or from chestnut phyllosphere (Valverde et al., 2005).

Ramos et al. (2011) isolated and identified Stenotrophomonas pavanii JST3 from the stems of Brazilian sugar cane, which possesses nitrogen-fixing capacity. Notably, we have observed $S$. warneri, S. epidermidis and B. frigoritolerans both in the roots and the shoots of the plant. It has been reported that bacteria in plant tissues are capable of migrating from soil to aerial parts of the plant through chemotaxis (Chi et al., 2005; Bulgarelli et al., 2013).

Bacteria use different mechanisms to improve plant health and fitness under stressed environmental conditions, such as salinity or drought. There are numerous reports in which endophytic bacteria stimulated plant growth and improved the resistance of a host plant to abiotic and biotic stresses, including drought and salt stress (Rashid et al., 2012; Egamberdieva et al., 2017c). The production of IAA by endophytic bacteria is considered to be an essential trait that modulates plant growth and physiology (Egamberdieva et al., 2017c). In our study, root-associated bacteria showed higher IAA synthesis activities compared with shoot-associated bacteria. The phytohormones produced by bacteria stimulate the growth and development of the root system architecture, which then facilitates the nutrient acquisition of plants under saline conditions (Piccoli et al., 2011; Egamberdieva et al., 2017a, c). Sorty et al. (2016) observed IAA production by several bacterial species isolated from a halotolerant weed (Psoralea corylifolia L.), including 
Acinetobacter, Enterobacter, Pseudomonas and Bacillus. The salt-tolerant strain P. fluorescens SPB2145 produced IAA, through which the root and shoot growth, nutrient uptake and plant stress tolerance of cucumber significantly increased (Egamberdieva et al., 2011). In our study, we observed that eight bacterial isolates produced IAA and stimulated root length. Interestingly, all of them were also able to produce ACC deaminase, which could cleave the plant ethylene precursor ACC, and thereby lowered the level of ethylene in a stressed plant (Glick, 2014). Our observations are in line with the results of Sgroy et al. (2009), showing that the endophytic bacteria isolated from the halophyte Prosopis strombulifera were positive for ACC deaminase activity. Gupta and Pandey (2019) reported that ACC deaminase producing bacteria Paenibacillus sp. alleviated the negative effects of salinity stress and increased root and shoot growth of French bean seedlings subjected to salinity stress. However, in our study two isolates of B. frigoritolerans, which produced ACC deaminase, but not IAA, or Staphylococcus strains that produce IAA but not ACC deaminase did not show any stimulation on plant growth. This finding indicates that multiple plant growth promoting activities vary with the trait and the isolate.

\section{Conclusions}

For the first time, we revealed the diversity of endophytic bacteria isolated from the roots and the shoots of the halophyte $S$. rosmarinus, grown on saline soil of Uzbekistan. The isolates belong to the genera Rothia, Kocuria, Pseudomonas, Staphylococcus, Paenibacillus, Brevibacterium, Stenotrophomonas, Halomonas, Planococcus and Planomicrobium. The most frequently isolated genus in the plant roots and shoots was Staphylococcus, which is known for its capacity of high salt tolerance. The root-associated bacteria showed higher levels of IAA synthesis compared with bacteria isolated from the plant shoots, as well as the production of ACC deaminase. Our findings suggest that halophytic plants could be a source for the selection of microbes that could improve plant fitness under saline soils. However, these findings also show that further research is necessary in pot as well as field experiments to resolve the impact of endophytic bacteria with selected plant growth promoting traits on plant growth and stress tolerance.

\section{Acknowledgements}

This research was supported by the Eurasia Program of the Norwegian Centre for Cooperation in Education (CPEA-LT-2016/10095), the German Academic Exchange Service (DAAD) and the President's International Fellowship Initiative of the Chinese Academy of Sciences (2018VBA002S).

\section{References}

Announ N, Mattei J, Jaoua S, et al. 2004. Multifocal discitis caused by Staphylococcus warneri. Joint Bone Spine, 71(3): 240-242.

Bano N, Musarrat J. 2003. Characterization of a new Pseudomonas aeruginosa strain NJ-15 as a potential biocontrol agent. Current Microbiology, 46(5): 324-328.

Barigye R, Schaan L, Gibbs P S, et al. 2007. Diagnostic evidence of Staphylococcus warneri as a possible cause of bovine abortion. Journal of Veterinary Diagnostic Investigation, 19(6): 694-696.

Bulgarelli D, Schlaeppi K, Spaepen S, et al. 2013. Structure and functions of the bacterial microbiota of plants. Annual Review of Plant Biology, 64: 807-838.

Chi F, Shen S H, Cheng H P, et al. 2005. Ascending migration of endophytic rhizobia, from roots to leaves, inside rice plants and assessment of benefits to rice growth physiology. Applied and Environmental Microbiology, 71(11): 7271-7278.

Cho S T, Chang H H, Egamberdieva D, et al. 2015. Genome analysis of Pseudomonas fluorescens PCL1751: a rhizobacterium that controls root diseases and alleviates salt stress for its plant host. PLoS ONE, 10(10): e0140231.

Chou Y J, Chou J H, Lin K Y, et al. 2008. Rothia terrae sp. nov. isolated from soil in Taiwan. International Journal of Systematic and Evolutionary Microbiology, 58(1): 84-88.

Dashti A A, Jadaon M M, Abdulsamad A M, et al. 2009. Heat treatment of bacteria: a simple method of DNA extraction for molecular techniques. Kuwait Medical Journal, 41(2): 117-122.

Egamberdieva D, Kamilova F, Validov S, et al. 2008. High incidence of plant growth-stimulating bacteria associated with the rhizosphere of wheat grown in salinated soil in Uzbekistan. Environmental Microbiology, 10(1): 1-9. 
Egamberdieva D, Kucharova Z, Davranov K, et al. 2011. Bacteria able to control foot and root rot and to promote growth of cucumber in salinated soils. Biology and Fertility of Soils, 47: 197-205.

Egamberdieva D, Li L, Lindström K, et al. 2015. A synergistic interaction between salt tolerant Pseudomonas and Mesorhizobium strains improves growth and symbiotic performance of liquorice (Glycyrrhiza uralensis Fish.) under salt stress. Applied Microbiology and Biotechnology, 100: 2829-2841.

Egamberdieva D, Li L, Wirth S, et al. 2017. Microbial cooperation in the rhizosphere improves liquorice growth under salt stress. Bioengineered, 8(4): 433-438.

Egamberdieva D, Wirth S J, Behrendt U, et al. 2017a. Antimicrobial activity of medicinal plants correlates with the proportion of antagonistic endophytes. Frontiers in Microbiology, 8: 199.

Egamberdieva D, Wirth S J, Shurigin V V, et al. 2017b. Endophytic bacteria improve plant growth, symbiotic performance of chickpea (Cicer arietinum L.) and induce suppression of root rot caused by Fusarium solani under salt stress. Frontiers in Microbiology, 8: 1887.

Egamberdieva D, Wirth S J, Alqarawi A A, et al. 2017c. Phytohormones and beneficial microbes: essential components for plants to balance stress and fitness. Frontiers in Microbiology, 8: 2104.

El Shaer H M. 2010. Halophytes and salt-tolerant plants as potential forage for ruminants in the Near East region. Small Ruminant Research, 91(1): 3-12.

Etesami H, Beattie G A. 2017. Plant-microbe interactions in adaptation of agricultural crops to abiotic stress conditions. In: Kumar V, Kumar M, Sharma S, et al. Probiotics and Plant Health. Singapore: Springer, 163-200.

Etesami H, Beattie G A. 2018. Mining halophytes for plant growth-promoting halotolerant bacteria to enhance the salinity tolerance of non-halophytic crops. Frontiers in Microbiology, 9: 148.

Felsenstein J. 1985. Confidence limits on phylogenies: An approach using the bootstrap. Evolution, 39(4): $783-791$.

Flowers T J, Colmer T D. 2015. Plant salt tolerance: Adaptations in halophytes. Annals of Botany, 115(3): $327-331$.

Glick B R. 2014. Bacteria with ACC deaminase can promote plant growth and help to feed the world. Microbiological Research, 169(1): 30-39.

Grigore M N, Ivanescu L, Toma C. 2014. Halophytes: An Integrative Anatomical Study. New York: Springer, $39-43$.

Gupta S, Pandey S. 2019. ACC deaminase producing bacteria with multifarious plant growth promoting traits alleviates salinity stress in French bean (Phaseolus vulgaris) plants. Frontiers in Microbiology, 10: 1506.

Hadi M R. 2009. Biotechnological potentials of Seidlitzia rosmarinus: A mini review. African Journal of Biotechnology, 8(11): 2429-2431.

Hasanuzzaman M, Nahar K, Alam M, et al. 2014. Potential use of halophytes to remediate saline soils. BioMed Research International, 589341.

Hashem A, Abd Allah E F, Alqarawi A, et al. 2016. The interaction between arbuscular mycorrhizal fungi and endophytic bacteria enhances plant growth of Acacia gerrardii under salt stress. Frontiers in Microbiology, 7: 1089.

Jha B, Gontia I, Hartmann A. 2012. The roots of the halophyte Salicornia brachiata are a source of new halotolerant diazotrophic bacteria with plant growth-promoting potential. Plant and Soil, 356: 265-277.

Jinneman K C, Wetherington J H, Adams A M, et al. 1996. Differentiation of Cyclospora sp. and Eimeria spp. by using the polymerase chain reaction amplification products and restriction fragment length polymorphisms. Food and Drug Administration Laboratory Information Bulletin, 4044.

Kaplan D, Maymon M, Agapakis C M, et al. 2013. A survey of the microbial community in the rhizosphere of two dominant shrubs of the Negev Desert highlands, Zygophyllum dumosum (Zygophyllaceae) and Atriplex halimus (Amaranthaceae), using cultivation-dependent and cultivation-independent methods. American Journal of Botany, 100: 1713-1725.

Kaye J Z, Baross J A. 2000. High incidence of halotolerant bacteria in Pacific hydrothermal-vent and pelagic environments. FEMS Microbiology Ecology, 32(3): 249-260.

Kloos W E, Schleifer K H. 1975. Isolation and characterization of staphylococci from human skin II. descriptions of four new species: Staphylococcus warneri, Staphylococcus capitis, Staphylococcus hominis, and Staphylococcus simulans. International Journal of Systematic Bacteriology, 25(1): 62-79.

Kurkova E B, Kalinkina L G, Baburina O K, et al. 2002. Responses of Seidlitzia rosmarinus to salt stress. Biology Bulletin of the Russian Academy of Sciences, 29: 221-229.

Lane D J. 1991. 16S/23S rRNA Sequencing. In: Stackebrandt E, Goodfellow M. Nucleic Acid Techniques in Bacterial Systematic, New York: John Wiley and Sons, 115-175.

Ludwig-Mueller J. 2015. Plants and endophytes: equal partners in secondary metabolite production? Biotechnology Letters, 37 : 1325-1334.

Luo X, Zhang J, Li D, et al. 2014. Planomicrobium soli sp. nov., isolated from soil. International Journal of Systematic and Evolutionary Microbiology, 64: 2700-2705. 
Mishra A, Tanna B. 2017. Halophytes: potential resources for salt stress tolerance genes and promoters. Frontiers in Plant Science, 8: 829 .

Mora-Ruiz M D R, Font-Verdera F, Díaz-Gil C, et al. 2015. Moderate halophilic bacteria colonizing the phylloplane of halophytes of the subfamily Salicornioideae (Amaranthaceae). Systematic and Applied Microbiology, 38(6): 406-416.

Mora-Ruiz M D R, Font-Verdera F, Orfila A, et al. 2016. Endophytic microbial diversity of the halophyte Arthrocnemum macrostachyum across plant compartments. FEMS Microbiology Ecology, 92(9): fiw145.

Muchate N S, Nikalje G C, Rajurkar N S, et al. 2016. Plant salt stress: adaptive responses, tolerance mechanism and bioengineering for salt tolerance. The Botanical Review, 82: 371-406.

Mykytczuk N C, Wilhelm R C, Whyte L G, 2012. Planococcus halocryophilus sp. nov., an extreme sub-zero species from high Arctic permafrost. International Journal of Systematic and Evolutionary Microbiology, 62: 1937-1944.

Nanjani S G, Soni H P. 2014. Characterization of an extremely halotolerant Staphylococcus arlettae HPSSN35C isolated from Dwarka Beach, India. Journal of Basic Microbiology, 53(8): 1-8.

Nováková D, Sedlácek I, Pantůcek R, et al. 2006. Staphylococcus equorum and Staphylococcus succinus isolated from human clinical specimens. Journal of Medical Microbiology, 55(5): 523-528.

Piccoli P, Travaglia C, Cohen A, et al. 2011. An endophytic bacterium isolated from roots of the halophyte Prosopis strombulifera produces ABA, IAA, gibberellins $\mathrm{A}_{1}$ and $\mathrm{A}_{3}$ and jasmonic acid in chemically-defined culture medium. Plant Growth Regulation, 64: 207-210.

Ramos P L, van Trappen S, Thompson F L, et al. 2011. Screening for endophytic nitrogen-fixing bacteria in Brazilian sugar cane varieties used in organic farming and description of Stenotrophomonas pavanii sp. nov. International Journal of Systematic and Evolutionary Microbiology, 61(4): 926-931.

Rashid S, Charles T C, Glick B R. 2012. Isolation and characterization of new plant growth-promoting bacterial endophytes. Applied Soil Ecology, 61(4): 217-224.

Roohi A, Ahmed I, Iqbal M, et al. 2012. Preliminary isolation and characterization of halotolerant and halophilic bacteria from salt mines of Karak. Pakistan Journal of Botany, 44: 365-370.

Saitou N, Nei M. 1987. The neighbor-joining method: A new method for reconstructing phylogenetic trees. Molecular Biology and Evolution, 4(4): 406-425.

Sgroy V, Cassan F, Masciarelli O, et al. 2009. Isolation and characterization of endophytic plant growth-promoting (PGPB) or stress homeostasis-regulating (PSHB) bacteria associated to the halophyte Prosopis strombulifera. Applied Microbiology and Biotechnology, 85(2): 371-381.

Sorty A M, Meena K K, Choudhary K, et al. 2016. Effect of plant growth promoting bacteria associated with halophytic weed (Psoralea corylifolia L.) on germination and seedling growth of wheat under saline conditions. Applied Biochemistry and Biotechnology, 180: 872-882.

Surette M A, Sturz A V, Lada R R, et al. 2003. Bacterial endophytes in processing carrots (Daucus carota L. var. sativus): their localization, population density, biodiversity and their effects on plant growth. Plant and Soil, 253: 381-390.

Szymańska S, Płociniczak T, Piotrowska-Seget Z, et al. 2016. Metabolic potential and community structure of endophytic and rhizosphere bacteria associated with the roots of the halophyte Aster tripolium L. Microbiological Research, 182: 68-79.

Tamura K, Nei M, Kumar S. 2004. Prospects for inferring very large phylogenies by using the neighbor-joining method. Proceedings of the National Academy of Sciences of the United States of America, 101(30): 11030-11035.

Tamura K, Stecher G, Peterson D, et al. 2013. MEGA6: molecular evolutionary genetics analysis version 6.0. Molecular Biology and Evolution, 30(12): 2725-2729.

Toderich K N, Ismail S, Juylova E A, et al. 2008. New approaches for Biosaline Agriculture development, management and conservation of sandy desert ecosystems. In: Chedly A, Munir O, Muhamad A, et al. Biosaline Agriculture and Salinity Tolerance in Plant. Basel: Birkhauser Verlag, 247-264.

Valverde A, Igual J M, Santa R I, et al. 2005. Preliminary diversity studies of culturable phyllosphere bacteria on chestnut (Castanea sativa). Acta Horticulturae, 693: 263-270.

Yoon J H, Kang S S, Lee K C, et al. 2001. Planomicrobium koreense gen. nov., sp. nov., a bacterium isolated from the Korean traditional fermented seafood jeotgal, and transfer of Planococcus okeanokoites (Nakagawa et al., 1996) and Planococcus mcmeekinii (Junge et al., 1998) to the genus Planomicrobium. International Journal of Systematic and Evolutionary Microbiology, 51: 1511-1520.

Yoon J H, Kang S J, Lee S Y, et al. 2010. Planococcus salinarum sp. nov., isolated from a marine solar saltern, and emended description of the genus Planococcus. International Journal of Systematic and Evolutionary Microbiology, 60(4): 754-758.

You Y H, Park M J, Lee M C, et al. 2015. Characterization and phylogenetic analysis of halophilic bacteria isolated from rhizosphere soils of coastal plants in Dokdo Islands. Korean Journal of Microbiology, 51(1): 86-95.

Zhao S, Zhou N, Zhao Z Y, et al. 2016. Isolation of endophytic plant growth-promoting bacteria associated with the halophyte Salicornia europaea and evaluation of their promoting activity under salt stress. Current Microbiology, 73(4): 574-581. 